\title{
Effects of Instructional Aids on Students' Economics Achievement in Kware State, Nigeria
}

\section{Banjo M. Lawal}

Corresponding author, Department of Social Sciences Education, Faculty of Education, University of Ilorin, Nigeria, lawal_banjo@yahoo.com

Helen B. Victor-Akinyemi

Department of Curriculum and Instruction, Federal College of Education, Okene, Nigeria, bisfit13@gmail.com

The study examined the effects of instructional aids on Secondary Schools Students' Academic Achievement in Economics in Kwara State. Quasi-experimental design was used to execute the study. Two public secondary schools were randomly selected for the study. One hundred and twenty five students were purposefully selected from the two randomly selected public secondary schools in the study area. The students selected from the two schools were assigned to two groups in which one group was assigned to experimental and the other to control. The students in the experimental group were taught using instructional aids for six weeks by the researchers. Data were collected through Economics Achievement Test (EAT) designed by the researchers. The data were analyzed using Analysis of Covariance (ANCOVA). The study showed a significant difference in achievement mean scores of students in the experimental and control groups; and a non-significant interaction effect of gender and treatment on achievement mean scores of the students. It was therefore recommended that; students should corroborate the efforts of teachers in the provision of local instructional aids to enhance learning and promote academic performance in schools; and that teachers should always try their best to make use of available instructional materials where necessary to make their lessons more interesting.

Keywords: instructional aids, economics, achievement, students, Kwara State

\section{INTRODUCTION}

Economics is one of the subjects offered by Senior Secondary School Students in Nigeria. According to Dwivedi (2004) Economics is the study of how society decides what, how and for whom to produce goods which are physical commodities such as steel and strawberries and render services which are activities such as message or life concerts consumed or enjoyed only at the instant they are produced. He went further to say that the question of what, how and for whom to produce is either answered by a central planning agency or the price mechanism depending on the economic system practiced by a country. The level of understanding of Economics a student acquires will determine his ability in solving economic problems and making of rational decisions concerning the society. This suggests that student's ability to apply economics principles will be determined by academic performance in the subject.

Over the years, the society has been shifting the blame of poor performance of students in public examinations, especially in Economics, on the wrong choice of teaching methods by teachers.

Citation: Lawal, B. M., \& Victor-Akinyemi, H. B. (2018). Effects of Instructional Aids on Students' Economics Achievement in Kware State, Nigeria, Anatolian Journal of Education, 3(2), 19-24. https://doi.org/10.29333/aje.2018.322a 
Teaching and learning processes revolves around other variables, such as instructional aids, teacher's qualification, school environment variables, students' factors and so on. In this study, instructional aid is the main focus in order to unveil their effects on the academic performance of students. The place of Instructional Aids in any teaching/learning process cannot be over emphasized. This is for the fact that such materials enhance, facilitate and make teaching/learning easy, lively and concrete.

Instructional aids are the devices acquired, developed or improvised to assist or facilitate teachers in communicating an organized knowledge, skills and attitudes to the learners during teaching and learning process (Nwachukwu, 2006). According to Mbipom (2000) teacher uses instructional aids to achieve his set objectives because the sequence in which learners encounter materials will have both direct and indirect effects on the achievement of the material. Providing closer experience to real situation during instructional process could enhance acquisition and retention of factual information. it is in line with this that Umaru (2011) opined that instructional aids will not only provide the necessary concrete experience but it will also help to promote understanding of the concept and generalization by making the instructional process practical and realistic. Hence, the influence of instructional materials in promoting students' academic performance is indisputable. As such, schools should try and provide necessary learning aid that will compliment teacher's efforts because the teacher alone cannot provide all the needed conditions for effective teaching and learning process.

Conflicting submissions, however, have been made from different studies regarding influence of instructional aids on academic achievement. Egbona (2002) studied the extent to which instructional materials are made available for the teaching-learning process and found that availability of instructional materials has no significant relationship with academic performance of students. Also, Esu, Enukoha and Umoren (2004) found that teaching aids are indispensable to the effective teaching and learning activities and successful instructional delivery in schools. Contrariwise, Etim (2001) explored how availability of instructional materials influences academic performance of students in economics in Calabar municipal, Etim discovered that most of the schools visited did not have any instructional materials for teaching economics. The result of the study reported positive influence of instructional materials on academic performance in favour of schools that have instructional materials.

As good as instructional aids in instructional processes, it is disheartening that most economics teachers are not grounded in the selection and use of viable instructional aids and as such the teaching and learning of economics has not been optimal. The poor performance of students in economics is evident in the overall results of students in such examinations as the General Certificate in Education (G.C.E) and Senior Secondary School Certificate Examinations S.S.C.E. Despite the efforts being made by Economics teachers to facelift the performance of students in the subject, it appears much is still left to be done (Ankomah \& Kwarteng, 2010). Many teaching methods and approaches have been introduced but could not improve the achievement of students in economics. Teachers teach the subject matter in abstraction thereby making it comprehensive and arduous task for learners and this has militated against the maximization of academic performance. This study is, therefore, designed to examine the effect of instructional aids on students' economics achievement in Kwara State. Specifically the study sought to:

1. determine the differences in achievement mean scores of students in the experimental and control groups

2. determine the interaction effect of gender and treatment on achievement mean scores of the students.

To achieve the purpose of the study, the following null hypotheses guided the researcher in the course of the study.

1. There is no significant difference in achievement mean scores of students in the experimental and control groups. 
2. There is no significant interaction effect of gender and treatment on achievement mean scores of the students.

\section{METHOD}

\section{Research Design}

Quasi-experimental pre-test post-test control group design was adopted in this study. The pre-test was used to test the previous knowledge of the students used for the study and post-test to measure their level of achievement after treatment. Two groups were involved in the study in which one group was assigned to experimental and the other to control. The two groups responded to pre-test before the experiment took place. Various instructional materials such as maps, charts, pictures, diagrams, stamps, envelops, handsets, newspapers, magazines, computers and projectors were used to teach students in the experimental group while the control group was taught with normal conventional method without any teaching aid. The treatment which lasted for six weeks was implemented by the researchers. During the experiment, the researchers systematically relayed contents of instruction to the students with the aid of the materials for better understanding and retention. After the treatment lessons for the experimental group, the post-test was administered on the two groups to test their level of achievement.

\section{Population and Sample}

The population for the study was all Senior Secondary students in Kwara State while the sample was 125 Senior Secondary School Class II students selected from two schools. Purposive sampling was used to select two schools and 125 students from two intact classes (61 from the firs school and 64 from the second school).

\section{Instrumentation}

The instrument for the study was a self-designed questionnaire titled "Economics Achievement Test (EAT). It was made up of 40 multiple-choice items based on current Economics curriculum. Parts of the questions in the achievement test are: (1) Amount proposed for payments of wages and salaries in a budget is regarded as part of ___ (2) The direct exchange of one goods for another without the use of money is known as _ (3) The type of market in which there is only one buyer of a product is called__, and (4) The price elasticity of a horizontal demand curve is __. The instrument was validated by Economics teachers and Test and Measurement experts. Test-re-test and estimation of internal consistency were used to determine the reliability of the instrument. The test-re-test of the instrument was done by giving it as a test to 25 students from 2 schools that were not part of the study. After three weeks, the same sets of students were given the same test. Pearson Product Moment Correlation Coefficient Analysis was used to determine the scores of the two sets. The correlation coefficient of 0.77 was obtained.

\section{Data Analysis}

Analysis of Covariance (ANCOVA) was used for analyses of the data collected. The statistical tool was considered appropriate because enabled the researchers in controlling for the effects of pre-test which is not of primary interest, known as covariates.

\section{.FINDINGS}

Hypothesis 1: There is no significant difference in achievement mean scores of students in the experimental and control groups 
Table 1

Analysis of Covariance on difference in achievement mean scores of students in the experimental and control groups

\begin{tabular}{llllll}
\hline Source & Type III Sum of Squares & Df & Mean Square & F & Sig. \\
\hline Corrected Model & $504.262^{\mathrm{a}}$ & 2 & 252.131 & 29.872 & .000 \\
Intercept & 2624.747 & 1 & 2624.747 & 310.971 & .000 \\
Achievement Pretest & 85.225 & 1 & 85.225 & 10.097 & .002 \\
Groups & 476.081 & 1 & 476.081 & 56.404 & .000 \\
Error & 1029.738 & 122 & 8.440 & & \\
Total & 69979.000 & 125 & & & \\
Corrected Total & 1534.000 & 124 & & & \\
\hline
\end{tabular}

Table 1 shows the calculated F-value of 56.404 and p-value of 0.000 which is less than 0.05 level of significance $(0.000<0.05)$. Since the p-value of 0.000 is less than the significance value of 0.05 , the null hypothesis which states that there is no significant difference in achievement mean scores of students in the experimental and control groups is not accepted. This means that there is significant difference in achievement mean scores of students in the experimental and control groups. To determine where the differences lies, discriptive analysis of the scores obtained from the two groups was performed. The differences can be seen in the descriptive table presented in table 2 below.

Table 2

Descriptive analysis of the difference in the achievement mean score of students in the experimental and control groups

\begin{tabular}{llll}
\hline Groups & Mean & Std. Deviation & $\mathrm{N}$ \\
\hline Experimental Group & 25.1875 & 3.05959 & 64 \\
Control Group & 21.5246 & 2.95864 & 61 \\
\hline
\end{tabular}

Table 2 shows that the average mean score of the experimental group is greater than that of the control group. This means that the experimental group (group taught with instructional aids) outperformed their counterparts (group taught with conventional method). Since the experimental group outperformed their counterparts, it means that the treatment (instructional aids) was effective in the teaching and learning of Economics.

Hypothesis 2: There is no significant interaction effect of gender and treatment on achievement mean scores of the students.

Table 3

Analysis of Covariance (ANCOVA) on interaction effect of gender and treatment on achievement mean scores of the students

\begin{tabular}{llllll}
\hline Source & $\begin{array}{l}\text { Type III Sum of } \\
\text { Squares }\end{array}$ & Df & Mean Square & F & Sig. \\
\hline Corrected Model & $577.692^{\mathrm{a}}$ & 4 & 144.423 & 18.123 & .000 \\
Intercept & 2690.252 & 1 & 2690.252 & 337.580 & .000 \\
Achievement Pretest & 64.950 & 1 & 64.950 & 8.150 & .005 \\
Groups & 449.262 & 1 & 449.262 & 56.375 & .000 \\
Gender & 33.124 & 1 & 33.124 & 4.156 & .064 \\
Groups * Gender & 39.210 & 1 & 39.210 & 4.920 & .208 \\
Error & 956.308 & 120 & 7.969 & & \\
Total & 69979.000 & 125 & & & \\
Corrected Total & 1534.000 & 124 & & & \\
\hline
\end{tabular}

Table 3 shows that the calculated F-value of 4.920 and p-value of 0.208 which is greater than 0.05 level of significance $(0.208>0.05)$. Since the p-value is greater than 0.05 , the null hypothesis which 
states that there is no significant interaction effects of gender and treatment on achievement mean scores of the students is not rejected. This means that there is no significant interaction effects of gender and treatment on achievement mean scores of the students.

\section{DISCUSSION}

This study found that students in the experimental group (students taught with instructional aids) performed better than students in the control group in their achievement mean scores. The study corroborates the findings of Esu, Enukoha and Umoren (2004) found that teaching aids are indispensable to the effective teaching and learning activities and successful instructional delivery in schools. As such the place of instructional material should not be taken for granted in teachinglearning processes.

This study also confirmed that there is no interaction effects of gender and treatment on achievement mean scores of the students. This means that gender does not affect the treatment given to the students. Both male and female students in the treatment group perform at the same level. The finding is in contrary to Okoye (2009) which revealed interaction effects of gender on students' academic achievement.

Based on the findings, it was suggested that students should corroborate the efforts of other teachers in the provision of local instructional aids to enhance learning and promote academic performance in schools; and that teachers should always try their best to make use of available instructional materials where necessary to make their lessons more interesting.

\section{CONCLUSION}

This study analyzed effects of instructional aids on students' economics achievement in Kwara State, Nigeria. Related literature review was made considering scholars explanation of the subject matter. Quasi-experimental pre-test post-test control group design was adopted in this study and 125 students from two intact classes were sampled for the study. Relevant data for the study was generated through economics achievement test. Two null hypotheses were formulated and tested in the study using Analysis of Covariance (ANCOVA). The finding of this study revealed that students in the experimental group (students taught with instructional aids) performed better than students in the control group in their achievement mean scores, and that no interaction effects of gender and treatment on achievement mean scores of the students. It is concluded from this study that the place of instructional aids in the effective teaching-learning processes and attainment of teaching/learning objectives cannot be jettisoned. The students taught with instructional aids have good academic performance compared with those taught without any material.

\section{REFERENCES}

Ankomah, Y. A. \& Kwarteng, J. T. (2010). Concerns of accounting teachers about the implementation of the 2007 Education Reform. International Journal for Educational Leadership 2(2), 1-11

Dwivedi, D.N. (2004). Management economics (6th edition). London: Martin press inc.

Esu, A.E.O., Enukoha, O.I.T., \& Umorem, G. U. (2004). Curriculum development in Nigeria for colleges and universities. Owerri: Whyte and Whyte Publishers.

Etim, O. (2001). - Preparing the Primary School Social Studies Teachers. West African Journal of Education XIX.

Mbipom, G. (2000). Educational Administration and planning. Calabar: University of Calabar Press. 
Nwachukwu CE (2006). Designing Appropriate Methodology in Vocational and Technical Education for Nigeria, Nsukka, University, Trust Publishers.

Okoye, N.S. (2009). The effects of the writing process method on students' performance in English composition, Ph. D Thesis. University of Nigeria, Nsukka.

Umaru, K. I (2011) influence of instructional materials on the academic performance of students in Agricultural Science in Secondary Schools in Kwara State, Nigeria. M.Sc in Agricultural Science Education of Ahmadu Bello University 